\title{
Analisis Penganggaran Belanja Pada Satuan Kerja Di Lingkungan Kementerian Keuangan Wilayah Sulawesi Utara
} WILMA DEODORA ENGELINA ${ }^{1}$, LINTJE KALANGI ${ }^{2}$, LINDA LAMBEY ${ }^{3}$

1,2,3 Program Magister Akuntansi, Fakultas Ekonomi dan Bisnis Universitas Sam Ratulangi email: pingkanwilma@gmail.com ${ }^{1}$, lintjekalangi@yahoo.com ${ }^{2}$, lindalambey@yahoo.com ${ }^{3}$

\begin{abstract}
Document resulting from budgeted expenditure at work unit in the Ministry of Finance is issued in the form of DIPA and the implementation of expenditure of work unit is carried out based on DIPA. It thus should be arranged in DIPA as a document budget resulted from a good planning process as determined in the legislation. However, it is not uncommon for the work unit to experience changes in activities that ultimately show a significant difference between planned and actual budget. The difference is evident and can be seen in the Rencana Penarikan Dana on page III DIPA in the Budget Realization Report of the work units. This study aims to analyze the obstacles experienced by 'Satker' in budgeting and strategic steps taken by the satker in carrying out its budget expenditure. This is a qualitative exploratory research. Data were obtained through in-depth interviews, documentation study and observation. Key informants were determined by using purposive sampling. Informants must meet criterias in order to obtain accurate and precise information. Triangulation techniques were used to test the validity of data and data sources. Interview transcirptions were analyzed by content analysis.The result of the research indicates that budgeting in work unit has been determined in accordance to law regulations. On the other hand, the obstacles experienced by 'Satker' are (1) the insufficient human resources in quantity and competence related to budget planning at the GKN Manado and KPPBC Manado. This is because the quality of human resources also determines the disposition or attitude of the implementer on the task and function, (2) poor communication with agencies or parties outside the work unit, (2) improper bureaucratic structures resulting to insufficiency of the human resources availability for budgeting. Strategies that can be implemented to overcome those obstacles are to (1) provide competent and skilled human resources, (2) establish good communication, (3) motivate leaders to be committed and provide their excellent leaderships in order to achieve the organizational goals.
\end{abstract}

Keywords: Analysis, Budgeting, Work Units of the Ministry of Finance

Abstrak. Dokumen hasil penganggaran belanja pada satuan kerja di lingkungan Kementerian Keuangan dikeluarkan dalam bentuk DIPA dan penyelenggaraan belanja satker dilaksanakan berdasarkan DIPA tersebut. Sehingga sudah seharusnya yang tersusun di dalam DIPA sebagai dokumen anggaran melalui proses perencanaan yang baik sebagaimana yang tertuang dalam peraturan perundang-undangan. Namun demikian, tidak jarang satker mengalami perubahan kegiatan yang pada akhirnya memperlihatkan perbedaan yang cukup signifikan antara yang direncanakan dengan realisasi anggaran yang dilaksanakan. Perbedaan tersebut terlihat dari Rencana Penarikan Dana pada halaman III DIPA dengan Laporan Realisasi Anggaran satker. Penelitian ini bertujuan untuk menganalisis bagaimana proses penganggaran belanja, kendala yang dihadapi satker dalam penganggaran belanja serta langkah-langkah strategis dalam upaya mengatasi kendala. Penelitian ini menggunakan metode kualitatif dengan pendekatan eksploratif. Data diperoleh melalui teknik in-depth interview, studi dokumentasi, dan obervasi. Informan kunci ditetapkan secara purposive sampling dengan syarat memenuhi kriteria yang ditetapkan untuk mendapatkan informasi yang tepat dan akurat. Teknik triangulasi digunakan untuk menguji validitas data dan sumber data. Data transkrip yang diuraikan dari hasil wawancara dianalisis menggunakan metode content analysis. Hasil penelitian menunjukkan bahwa dalam penganggaran belanja satker telah dibekali dasar hukum yang menjadi panduannya. Kendala yang dihadapi satker adalah (1)SDM yang belum memadai secara kuantitas maupun kompetensi terkait dengan perencanaan anggaran pada satker GKN Manado dan KPPBC Manado, kualitas SDM juga menentukan disposisi atau sikap pelaksana pada tugas dan fungsinya, (2) komunikasi yang kurang baik dengan instansi atau pihak di luar satker, (3) struktur birokrasi yang kurang tepat menjadi kendala pada ketersediaan SDM atau penganggaran belanja. Strategi yang dapat dilakukan untuk mengatasi kendala menganalisis dengan tepat mulai dari proses penganggaran belanja. Hal ini perlu didukung dengan SDM sesuai kebutuhan dan berkompeten, sehingga terbangun komunikasi yang baik, diperlukan komitmen pimpinan untuk tetap fokus kepada tujuan organisasi.

Kata Kunci: Penganggaran, Anggaran Belanja, Satker Kementerian Keuangan. 


\section{Pendahuluan}

Berdasarkan Undang-undang Nomor 17 Tahun 2003 Tentang Keuangan Negara disebutkan bahwa anggaran adalah alat akuntabilitas, manajemen, dan kebijakan ekonomi. Sebagai instrumen kebijakan ekonomi anggaran berfungsi untuk mewujudkan pertumbuhan dan stabilitas perekonomian serta pemerataan pendapatan dalam rangka mencapai tujuan bernegara. Hal ini menujukan betapa pentingnya anggaran dalam pelaksanaan bernegara. Anggaran dapat diinterpretasikan sebagai paket pernyataan menyangkut perkiraan penerimaan dan pengeluaran yang diharapkan akan terjadi dalam satu atau beberapa periode mendatang (Bastian, 2010: 191). Pemerintah sebagai amanat dari Undangundang Dasar 1945 antara lain berkewajiban untuk memajukan kesejahteraan umum dengan mengelola keuangan negara dalam suatu sistem pengelolaan keuangan negara yang dituangkan dalam Anggaran Pendapatan Belanja Negara (APBN). APBN adalah rencana keuangan tahunan pemerintahan negara yang disetujui oleh Dewan Perwakilan Rakyat (DPR) dan dikelola secara tertib, taat pada peraturan perundang-undangan, efisien, ekonomis, efektif, transparan, dan bertanggung jawab dengan memperhatikan rasa keadilan dan kepatutan. Untuk melaksanakan APBN dimulai dengan penyusunan dan pengesahan dokumen pelaksanaan anggaran yang disebut dengan Daftar Isian Pelaksanaan Anggaran (DIPA). DIPA disusun oleh Pengguna Anggaran (PA) berdasarkan rincian yang tercantum dalam APBN. Untuk Satuan Kerja (Satker) sebagai kepanjangan tangan dari Kementerian Keuangan di daerah digunakan DIPA Petikan yang dicetak secara otomatis melalui sistem, yang berisi mengenai informasi kinerja, rincian pengeluaran, rencana penarikan dana dan perkiraan penerimaan, dan catatan yang berfungsi sebagai dasar pelaksanaan kegiatan satker.

Proses penganggaran yang baik tentu mempengaruhi penyerapan anggaran pula, hal ini dibuktikan dalam beberapa penelitian sebelumnya. Faktor yang utama adalah faktor perencanaan. Perencanaan anggaran yang akurat akan memudahkan tahap pelaksanaan anggaran dan memungkinkan tercapainya target secara efektif (Jauhari, 2017: 6). Dengan adanya perencanaan yang baik tentunya kualitas DIPA juga menjadi lebih baik. Kondisi penyerapan anggaran yang kurang baik memperlihatkan bahwa Kementerian Negara/Lembaga (selanjutnya disebut dengan K/L) belum optimal dalam menyusun rencana pelaksanaan kegiatan dalam rencana penarikan dana, juga dalam pengawasan implementasinya.

Dalam konteks manajemen kas sektor publik, tujuan utama dari perencanaan adalah untuk memberikan pedoman yang cukup dan tepat waktu dalam rangka menentukan tindakan untuk mencapai pengendalian yang baik atas arus kas organisasi (Murwanto, Insyafiah, dan Subkhan, 2006: 9). Pelaksanaan kegiatan yang dilakukan sesuai rencana akan berdampak pada terbentuknya pola penyerapan yang teratur, sehingga dapat memberikan kepastian waktu dan jumlah penarikan dana dalam rangka penyusunan perencanaan kas yang baik oleh Menteri Keuangan selaku Bendahara Umum Negara. Hal tersebut dapat dimanfaatkan sebagai bahan monitoring dan evaluasi atas pelaksanaan suatu kegiatan untuk kemudian dijadikan sebagai bahan perbaikan tahap pelaksanaan berikutnya. Dilansir dari CNN Indonesia (Gumelar, 2018), Menteri Keuangan Sri Mulyani Indrawati mengungkapkan bahwa menurut data yang dimilikinya terdapat 52.400 revisi DIPA yang diajukan oleh 26 ribu satker di seluruh Indonesia sepanjang tahun lalu dan atas fenomena tersebut ia akan memberikan punishment berupa penghentian anggaran kepada satuan kerja di bawah Kementerian Negara/ Lembaga jika banyak melakukan revisi DIPA untuk tahun depan. Beliau berpendapat semakin banyak revisi DIPA menunjukkan satker di bawah K/L tidak becus dalam merencanakan anggaran.

Fenomena yang terjadi pada satker Gedung Keuangan Negara (GKN) Manado diketahui bahwa realisasi anggaran belanja barang pada satker GKN Manado melampaui rencana penarikan dana setiap bulannya dengan kisaran di atas 100\%, sejak bulan Januari sampai dengan bulan Juni 2016. Kemudian realisasi anggaran belanja barang menurun di kisaran 50\% sampai dengan di bawah $80 \%$ dari rencana penarikan dana mulai bulan Agustus sampai dengan Desember 2016. Sedangkan pada belanja modal satker GKN Manado diketahui bahwa realisasi belanja modal pada Tahun Anggaran (selanjutnya disebut dengan TA) 2016 telah dianggarkan setiap bulannya dari bulan Januari 2016 namun baru terealisasi dengan signifikan di akhir TA 2016.

Pada satker Kantor Pengawasan dan Pelayanan Bea dan Cukai Manado diketahui bahwa pada realisasi belanja barang TA 2016 hanya mencapai kisaran 25\% sampai dengan 70\% dari perencanaan penarikan dana hampir di setiap bulan dan naik secara signifikan pada akhir TA 2016. Sedangkan untuk belanja modalnya menunjukan bahwa KPPBC Manado dalam beberapa bulan telah merencanakan penarikan dana namun tidak terealisasi pada bulan tersebut, kemudian merencanakan penarikan dana secara signifikan pada bulan Juli 2016 dan baru terealisasi pada bulan September 2016. 
Banyak hal yang menjadikan realisasi anggaran belanja tidak sesuai dengan yang direncanakan sebelumnya termasuk anggapan bahwa anggaran yang diusulkan nantinya tidak akan disetujui semua, akibatnya anggaran yang diusulkan lebih besar dari yang dibutuhkan atau bahkan perencanaan yang diajukan oleh satker tidak memiliki perencanaan yang jelas, matang, dan terarah sehingga anggaran yang direncanakan jauh lebih kecil dari realisasinya atau adanya efisiensi dalam pelaksanaan anggaran belanja. Hal ini yang dirasa perlu untuk diteliti lebih lanjut dan berdasarkan fenomena yang telah diuraikan menarik penulis untuk menelusuri lebih mendalam terkait dengan penganggaran yang terjadi pada satker Kementerian Keuangan di wilayah Sulawesi Utara pada satker GKN Manado dan KPPBC Manado dengan judul Analisis Penganggaran Belanja Pada Satuan Kerja Di Lingkungan Kementerian Keuangan Wilayah Sulawesi Utara, menganalisis kendala-kendala yang dihadapi satker GKN Manado dan KPPBC Manado serta langkah strategis sebagai upaya untuk mengatasi kendala dalam penganggaran belanja yang lebih baik.

Tujuan dilakukannya penelitian ini adalah untuk : 1) menganalisis kendala yang dihadapi oleh satker GKN Manado dan KPPBC Manado dalam penganggaran belanja; dan 2) untuk menganalisis langkah-langkah strategis dalam upaya mengatasi kendala yang dihadapi oleh satker GKN Manado dan KPPBC Manado dalam penganggaran belanja. Hasil penelitian ini diharapkan dapat memberikan manfaat yang berarti baik bagi satker Kementerian Keuangan maupun Pemerintah Daerah. Bagi satker K/L di wilayah Sulawesi Utara, khususnya satker Kementerian Keuangan di wilayah Sulawesi Utara diharapkan menjadi masukan dalam upaya mengoptimalkan penganggaran belanja. Bagi para akademisi hasil penelitian ini diharapkan dapat memberikan kontribusi terhadap pengembangan literatur dan referensi bagi mahasiswa, selanjutnya dapat dijadikan sebagai acuan guna penelitian lanjutan.

\section{Model Analisis}

Model analisis pada penelitian ini dimulai dengan melihat fenomena yang terjadi pada penganggaran belanja pada satker GKN Manado dan KPPBC Manado. Selanjutnya membangun proposisi, kemudian melakukan pengumpulan data dengan teknik wawancara dan didukung dengan studi dokumentasi dan observasi terkait dengan penganggaran belanja yang berlaku, kendala-kendala yang dihadapi oleh satker serta langkah strategi sebagai upaya mengatasi kendala yang ada, kemudian menganalisis dengan teori-teori yang ada dan peraturan terkait penganggaran belanja, sehingga tercapai hasil penelitian.

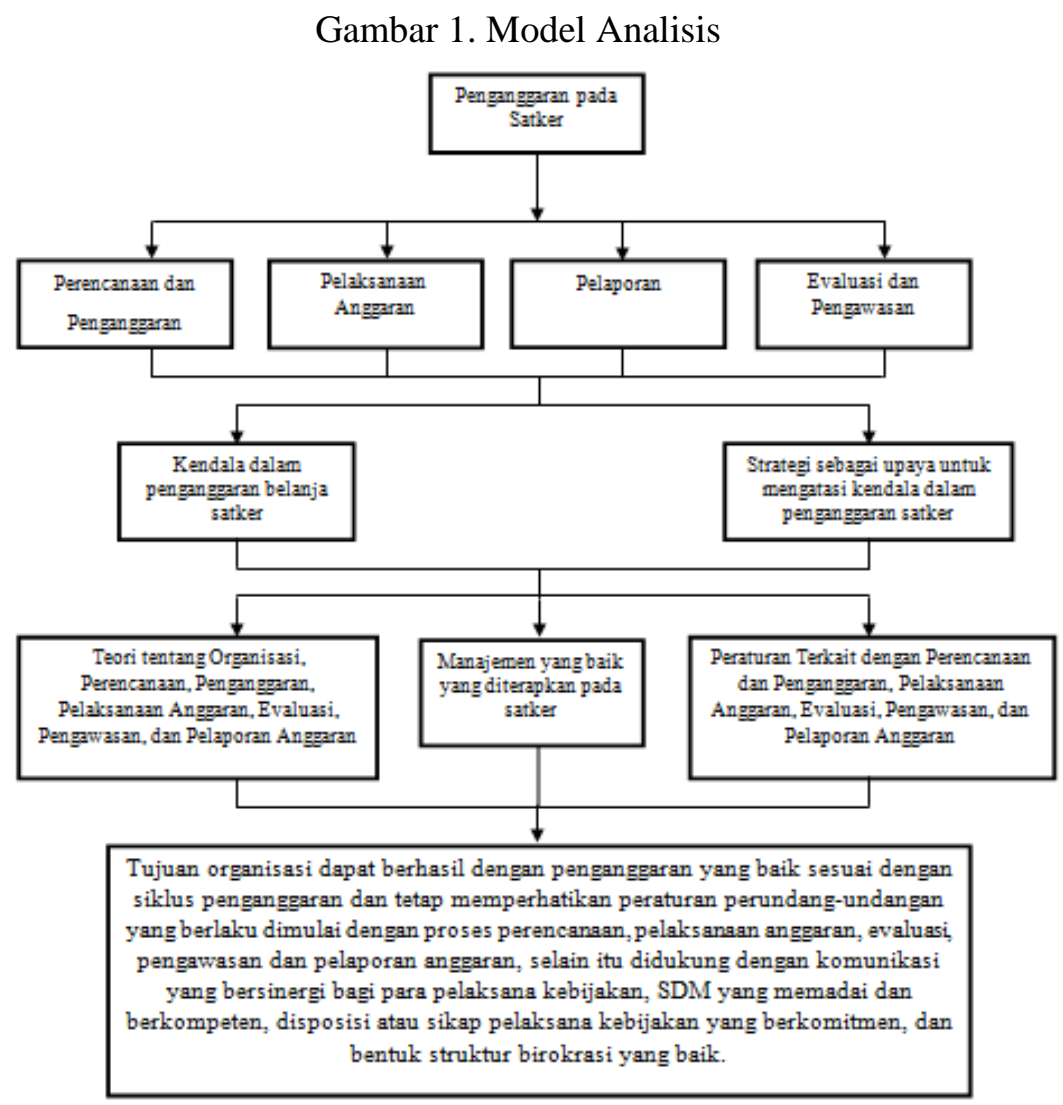




\section{Metode Penelitian}

Penelitian ini menggunakan metode pendekatan kualitatif. Jenis penelitian kualitatif adalah penelitian yang digunakan untuk meneliti pada kondisi obyek yang alamiah, dimana peneliti adalah sebagai instrumen kunci, teknik pengumpulan data dilakukan secara triangulasi (gabungan), analisis data bersifat induktif, dan hasil penelitian kualitatif lebih menekankan makna dari pada generalisasi (Sugiyono, $2015:$ 1). Jenis kualitatif dipilih karena jenis penelitian ini menemukan data yang secara langsung memahami makna dibalik fenomena yang ada, baik itu melalui wawancara, studi dokumentasi, dan observasi. Penelitian ini menggunakan penelitian dengan metode eksploratif. Dalam konteks penelitian, eksplorasi adalah salah satu dari metode (cara kerja) yang bisa digunakan dalam penetilitan kualitatif. Dalam hal ini, eksplorasi adalah usaha untuk membentuk pengertian umum dan awal terhadap suatu realitas yang diteliti, yang lebih mendalam dari sekedar penggambaran atau deskripsi. Dengan kata lain, metode eksplorasi dalam penelitian kualitatif adalah cara kerja penelitian yang dimaksudkan untuk menemukan lebih jauh dan mendalam terhadap kemungkinan-kemungkinan lain dari permasalahan yang diteliti (Ibrahim, 2015: 61). Metode ini digunakan oleh peneliti karena dapat menggambarkan secara mendalam tentang penganggaran belanja baik itu kendala dan strategi untuk mengatasi kendala yang dihadapi. Maksudnya, penelitian ini tidak hanya akan menggambarkan atau melukiskan sebagaimana realitas yang apa adanya, tetapi juga menggambarkan secara mendalam mengenai kendala-kendala yang dihadapi dalam penganggaran belanja, dan upaya-upaya yang dilakukan untuk mengatasi kendala-kendala yang dihadapi.

Teknik pengumpulan data yang dilakukan dalam penelitian ini adalah wawancara, studi dokumentasi dan observasi atau gabungan ketiganya yang disebut triangulasi. Informan kunci ditetapkan secara purposive sampling dengan syarat memenuhi kriteria yang ditetapkan untuk mendapatkan informasi yang tepat dan akurat. Metode analisis data dalam penelitian ini adalah dengan menggunakan content analysis, dimana dapat dimaknai sebagai kegiatan membahas dan memahami data guna menemukan makna, tafsiran dan kesimpulan tertentu dari keseluruhan data dalam penelitian. Setelah proses pengumpulan data pada penelitian ini selesai, maka data yang terkumpul dianalisis, disusun, dipilah dan disusun dengan sistematis dan bermakna. Dalam penelitian ini digunakan teks (tulisan maupun wacana) sebagai objek kajian atau satuan yang dianalisis (unit of analysis), dalam rangka menemukan makna atau isi pesan yang disampaikan. Uji keabsahan data yang diguunakan dalam penelitian ini meliputi uji validitas internal (credibility) dengan memanfaatkan triangulasi yang terdiri dari triangulasi sumber dan triangulasi teknik, uji reliabilitas (dependability) yang dilakukan oleh pembimbing mulai dari memeriksa keseluruhan aktifitas penelitian, mulai dari menentukan masalah/ fokus, menentukan sumber data, menentukan analisis data, melakukan uji keabsahan data dan sampai pada pembuatan kesimpulan/ laporan akhir.

\section{Analisis dan Pembahasan}

Penelitian dilakukan selama 3 (tiga) bulan sejak bulan Agustus sampai November 2017 dengan melakukan wawancara sesuai dengan pedoman wawancara kepada informan dengan menggunakan alat perekam untuk merekam seluruh isi wawancara, serta menggunakan instrumen pendukung antara lain buku catatan, alat perekam berupa audio, kamera untuk mendokumentasikan kegiatan di lapangan dan laptop untuk mengetik hasil penelitian dan rekaman wawancara sehingga berbentuk transkrip wawancara.

\section{Proses Penganggaran Belanja Pada Satuan Kerja GKN Manado dan KPPBC Manado}

Dalam proses perencanaan dan penganggaran pada satker GKN Manado dan KPPBC Manado dimulai dengan membuat dokumen RKA Satker dengan menggunakan aplikasi RKA-K/L pada masing-masing satker dan diajukan secara berjenjang kepada masing-masing Unit Eselon I menjadi RKA-K/L Unit Eselon I sampai dengan tingkat Kementerian Keuangan dalam bentuk RKA-K/L lingkup Kementerian/Lembaga. Secara teknis Unit Eselon I masing-masing terlebih dahulu bersurat kepada satkernya untuk segera mengumpulkan RKA Satker yang programnya sudah terencana dengan baik, kemudian proses penelitian RKA-K/L, reviu dan penelaahan RKA-K/L berjalan sampai dengan menggunakan aplikasi RKA-K/L, sampai dengan diterimanya DIPA Petikan. Pada saat DIPA Petikan diterima, halaman 3 DIPA memuat mengenai Rencana Penarikan Dana (RPD) satker. Dalam perencanaannya RPD diisi sesuai dengan rencana pelaksanaan kegiatan, pencantuman rencana penarikan dana dalam DIPA diperlukan sebagai alat manajemen kas pemerintah, dan sebagai alat monitoring/pembanding terhadap penyerapan pagu. Pengesahan DIPA oleh BUN memberi jaminan 
bahwa anggaran dalam DIPA dapat disediakan oleh negara dalam jumlah yang cukup pada saat anggaran tersebut ditagihkan.

Dalam proses pelaksanaan anggaran dilaksanakan dengan mengacu pada Peraturan Menteri Keuangan Nomor 190/PMK.05/2012 Tentang Tata Cara Pembayaran Dalam Rangka Pelaksanaan Anggaran Pendapatan dan Belanja Negara. Jenis belanja yang ada pada satker GKN Manado dan KPPBC Manado terdiri atas Belanja Pegawai, Belanja Modal, dan Belanja Barang. Pelaksanaan anggaran belanja yang dilaksanakan pada kedua satker juga mengacu pada DIPA Petikan masingmasing satker sebagai dokumen anggaran untuk mencapai outputnya. Sama halnya dengan proses perencanaan dan penganggaran, dalam pelaksanaan anggaran digunakan juga aplikasi yang merupakan perbaharuan dari aplikasi Surat Perintah Membayar (SPM) yang kita kenal sebelumnya dan telah digantikan dengan aplikasi Sistem Aplikasi Satker (SAS). Aplikasi SAS ini membantu para pengelola anggaran dan secara terintegrasi menggabungkan beberapa modul untuk Bendahara, PPK, PPSPM, sehingga apabila telah pelaksanaan anggaran telah sesuai, langkah berikutnya memasukkan data ke dalam aplikasi berikutnya. Salah satu dari produk SAS adalah dokumen SPM yang akan diajukan kepada KPPN. Namun demikian, tidak jarang KPPN mengembalikan berkas yang diajukan oleh satker karena beberapa hal seperti berkas yang diajukan belum lengkap atau salah untuk satker lengkapi sesuai dengan peraturan yang berlaku. Terkait dengan pelaksanaan anggaran, beberapa tahun belakangan ini Kementerian Keuangan giat dalam penghematan, dan tidak terkecuali berlaku juga kepada satker Kementerian Keuangan di daerah. Namun demikian, setelah dilakukan penghematan output yang dicapai terpenuhi oleh satker. Tentunya pelaksanaan kegiatan dan anggaran yang dilaksanakan oleh satker juga dipantau oleh KPA yang juga bertanggung jawab atas pelaksanaan kegiatan dan anggaran yang berada dalam penguasaannya.

Dalam pelaporannya, Satker menyampaikan laporan keuangannya kepada KPPN (Kantor Pelayanan Perbendaharaan Negara) setempat setiap bulan, dan kepada Kanwil maupun Unit Eselon I secara berjenjang. Dasar hukum yang digunakan dalam pelaporan ini Peraturan Menteri Keuangan Nomor 270/PMK.05/2014 tentang Penerapan Standar Akuntansi Pemerintahan Berbasis Akrual Pada Pemerintah Pusat. Dalam proses pelaporan satker juga menggunakan aplikasi untuk memproses transaksi keuangan dan barang sehingga menghasilkan Laporan Keuangan tingkat satker. Setiap bulannya satker menyampaikan laporan keuangan kepada KPPN dan menyampaikan laporan keungan setiap bulan dan semester disertai CaLK kepada Kanwilnya secara berjenjang sampai kepada Unit Eselon I. Selain itu satker juga melakukan rekonsiliasi. Rekonsiliasi juga dilakukan oleh satker dengan 2 (dua) macam rekonsiliasi, yaitu : (1) rekonsiliasi internal, yaitu rekonsiliasi data untuk penyusunan laporan keuangan yang dilaksanakan antar subsistem pada masing-masing Unit Akuntansi dan Pelaporan dan/atau antar Unit Akuntansi dan Pelaporan yang masih dalam satu entitas pelaporan; dan (2) rekonsiliasi eksternal, yaitu rekonsiliasi data untuk penyusunan laporan keuangan yang dilaksanakan antara Unit Akuntansi dan Pelaporan yang satu dengan Unit Akuntansi dan Pelaporan yang lain atau pihak lain yang terkait, tidak dalam satu entitas pelaporan. Pengelolaan anggaran belanja pada satker tidak terlepas dari terintegrasinya unit kerja satker secara berjenjang. Evaluasi, pengawasan, dan pembinaan terus selalu diterapkan sampai dengan lini satuan kerja di daerah. Sebagian terlihat pada sub bagian Pelaporan, dimana dengan adanya pelaporan dapat terlihat tindakan dari organisasi di atas satker. Evaluasi, pengawasan, dan pembinaan ini diberlakukan demi mencapai budaya kerja yang kontinu, segala perbaikan tetap terus menjadi hal yang tidak pernah berhenti sampai di pelaporan saja, namun sebagai tindak lanjut dari pelaporan. Dengan adanya rekonsiliasi laporan keuangan yang diterapkan pada tahapan dan jangka waktu tertentu dalam 1 (satu) tahun anggaran, maka pada saat itulah terjadi evaluasi, dan pembinaan. Sistem informasi yang terintegrasi sampai dengan unit eselon I masing-masing juga menjadi area pengawasan bagi unit eselon yang ada di atas satker secara berjenjang. Di dalam satker sendiri KPA dan PPK juga mempunyai tugas dan fungsi yang melekat untuk melakukan evaluasi, pengawasan, dan pembinaan, mulai dari perencanaan sampai dengan pelaporan sebelum disampaikan kepada unit eselon secara berjenjang. Dengan begitu diharapkan pengelolaan anggaran belanja dapat sesuai dengan tujuan dari masing-masing satker. Dengan kata lain, baik satker GKN Manado dan KPPBC Manado telah dibekali dengan peraturan terkait dengan penganggaran belanja yang berlaku bagi masing-masing satker di lingkungan Kementerian Keuangan.

Kendala Yang Dialami Oleh GKN Manado dan KPPBC Manado Dalam Penganggaran Belanja Ada 4 (empat) kendala yang ditemui dalam penganggaran belanja satker GKN Manado dan KPPBC Manado yaitu: 1) komunikasi; 2) sumber daya manusia; 3) disposisi atau sikap pelaksana; 4) 
struktur birokrasi. Keempat faktor tersebut menurut Geroge Edward III masih saling memiliki keterkaitan satu dengan yang lain atau dapat dikatakan saling mempengaruhi.

Kendala pertama yaitu komunikasi ditemukan pada proses penganggaran belanja satker, dimana komunikasi yang dibangun oleh satker dengan pihak eksternal satker belum maksimal. Hubungan komunikasi dengan pihak di luar satker di lingkungan Kementerian Keuangan di wilayah Sulawesi Utara masih belum maksimal. Tidak jarang satker di lingkungan Kementerian Keuangan wilayah Sulawesi Utara kurang membangun komunikasi yang baik, padahal sudah seharusnya satker lingkup Kementerian Keuangan saling bersinergi bekerja sama dalam menjalankan tugas dan fungsinya, sehingga saling mendukung untuk mewujudkan pelayanan yang baik bagi para stakeholder. Selain itu hubungan komunikasi antara satker dan pihak ketiga masih terkendala karena pihak ketiga sulit untuk dihubungi setelah pekerjaan telah selesai dikerjakan. Kendala komunikasi juga kerap terjadi antara satker dengan instansi pemerintah lainnya.

Kendala sumber daya manusia menjadi kendala utama bagi satker GKN Manado dan KPPBC Manado baik secara kuantitas dan kualitas. Pada GKN Manado pegawai yang ditempatkan adalah pegawai dari satker lingkup Kementerian Keuangan yang menempati GKN Manado, dalam hal ini pegawai diambil dari Kanwil Direktorat Jenderal Perbendaharaan provinsi Sulawesi Utara dan Kanwil Direktorat Jenderal Kekayaan Negara provinsi Sulawesi Utara, selain itu diambil pegawai honorer. Keterbatasan jumlah pegawai membuat Aparat Sipil Negara yang ditempatkan pada GKN Manado merangkap jabatan, hal ini juga disebabkan pegawai honorer memiliki kewenangan terbatas. Pada KPPBC Manado secara jumlah sebaran pegawai masih terbilang kurang, masih banyak pegawai yang merangkap jabatan, hal ini mengingat wilayah kerja KPPBC Manado sangat luas sampai dengan wilayah perbatasan Indonesia bagian Utara. Secara kompetensi dan kualitas pada kedua satker masih kurang pemahaman tentang pentingnya perencanaan anggaran yang tepat khususnya dalam menyusun Rencana Penarikan Dana sebagaimana pada halaman III DIPA satker. Kurangnya sebaran pegawai pada KPPBC Manado juga dirasakan ketika harus berbagi tugas untuk melakukan pengawasan dan pelayanan di daerah perbatasan, dimana banyak pos-pos Bea Cukai yang ditempatkan pada pulaupulau terdepan di wilayah perbatasan Indonesia bagian utara.

Dalam hal disposisi atau sikap pelaksana, pegawai yang mengalami rangkap jabatan pada kedua satker tersebut membutuhkan keterampilan dan komitmen dari pegawai itu sendiri dalam pelaksanakan tugas dan fungsinya. Hal ini menyebabkan adanya skala prioritas tugas dan fungsi yang lebih dahulu dikerjakan oleh pegawai. Komitmen antara pejabat dan pelaksana, diperlukan kesepakatan untuk dapat melaksanakan kebijakan terkait penganggaran belanja pada satker.

Secara struktur birokrasi, satker GKN Manado memiliki aturan bahwa dengan Keputusan Menteri Keuangan Nomor 418/KMK. 01/2012 Tentang Perwakilan Kementerian Keuangan, Sekretariat Perwakilan Kementerian Keuangan, Dan Pengelolaan Gedung Keuangan Negara Di Daerah yang menjelaskan bahwa Sekretariat Perwakilan Kementerian Keuangan dipimpin oleh seorang Kepala Sekretariat Perwakilan yang dipilih dari salah satu pejabat di lingkungan Kementerian Keuangan pada ibukota provinsi berkenaan. Dampaknya, pemangku jabatan pada GKN Manado mengambil pegawai dari satker unit lain lingkup Kementerian Keuangan untuk ditempatkan pula pada GKN Manado. Hal ini menjadikan pegawai GKN Manado merangkap jabatan dengan tugas dan fungsinya pada unit kerja di mana pegawai tersebut berasal.

\section{Strategi Sebagai Upaya Mengatasi Kendala Yang Dihadapi GKN Manado Dan KPPBC Manado Dalam Penganggaran Belanja}

Untuk menyelesaikan masalah dan kendala yang dihadapi oleh satker GKN Manado dan KPPBC Manado, maka upaya yang dilakukan adalah satker terus berupaya membangun komunikasi yang baik secara internal satker maupun eksternal satker. Eksternal satker maksudnya dengan pihak di luar satker baik itu masih dalam lingkup Kementerian Keuangan maupun dengan instansi lainnya di wilayah Sulawesi Utara dan pihak ketiga sebagai penyedia barang/jasa. Satker mengupayakan tetap berkomunikasi dengan lancar dengan unit eselon di atasnya. Kemudian komunikasi satker secara internal dibuat sedemikian lancar mulai dari pelaksana sampai dengan para pejabat yang ada, baik pimpinan maupun pelaksana saling memberikan informasi terkait penganggaran belanja, agar permasalahan dapat segera terselesaikan. Pada GKN Manado, pimpinan GKN Manado dan para pejabat satker yang menempati GKN Manado sedapat mungkin membangun komunikasi yang baik.

Upaya satker GKN Manado untuk mengatasi kekurangan sebaran pegawai adalah dengan cara menempatkan pegawai yang bekerja sebagai pelaksana dari pejabat yang bertugas di satker lain untuk 
ditempatkan di GKN Manado, sehingga koordinasi antara pejabat dengan staff pelaksana dapat lebih cepat. Staff pelaksana yang dipilih pun dengan memperhatikan kemampuan pegawai tersebut. Sedangkan pada KPPBC Manado bagi pegawai yang memiliki load pekerjaan terlalu tinggi kemudian dibagikan kepada pelaksana yang lainnya walaupun tidak sesuai dengan tugas dan fungsinya. Upaya yang dilakukan untuk pengembangan pegawai dilakukan oleh satker dengan cara menugaskan para pelaksana yang baru dalam rekonsiliasi keuangan yang rutin dilakukan oleh unit organisasi di atasnya satker, didampingi dengan pegawai senior yang berpengalaman sebagai mentornya. Selain itu sebelum pegawai yang baru menempati tugas dan fungsi yang baru, terlebih dahulu dilakukan transfer knowledge yang dilakukan oleh pegawai yang sebelumnya agar pegawai yang baru dapat mempelajari tugas dan fungsinya dengan lebih cepat. Peran dari Badan Pendidikan dan Pelatihan Keuangan juga menjadi penting dengan melakukan kegiatan pendidikan, pelatihan, monitoring, evaluasi, atau pembinaan bagi satker-satker di daerah. Peran unit eselon I sebagai organisasi di atas satker juga ikut berperan dengan rutin melaksanakan sosialisasi, bimbingan teknis, monitoring, dan evaluasi untuk pengembangan sumber daya manusia yang ada di satker terkait dengan penganggaran belanja satker, khususnya terkait dengan Rencana Penarikan Dana pada halaman III DIPA. Upaya pengembangan sumber daya manusia ini juga diperlukan untuk menambah kompetensi pegawai agar dapat diangkat sebagai Pejabat Pembuat Komitmen (PPK) di satker masing-masing agar satker memiliki pegawai yang memenuhi persyaratan untuk menjabat sebagai PPK. Sedangkan untuk mengatasi keterbatasan sumber daya manusia pada pos-pos Bea dan Cukai di pulau-pulau terdepan Indonesia bagian utara, satker KPPBC Manado menempatkan pegawai honorer yang memang berasal dari wilayah dimana pos-pos tersebut berada, sehingga pemantauan dapat dilakukan dengan menggunakan media komunikasi.

Terkait dengan disposisi atau sikap pelaksana, secara umum disposisi atau sikap pelaksana pada masing-masing satker sudah sangat baik, dalam arti para pegawai mengerti dan sadar betul dengan posisi dimana ia menjabat dan tahu apa yang harus dilakukan. Walaupun kendala untuk tidak merespon kebijakan dengan baik sangat dimungkinkan atau penolakan sangat dimungkinkan karena kondisi yang belum tentu sesuai dengan ekspektasi pegawai dapat saja terjadi. Banyak kondisi yang memungkinkan pegawai untuk merespon dengan kurang baik. Peran ganda yang diemban oleh pegawai juga mempengaruhi disposisi atau sikap pelaksana pada pegawai. Bagi pegawai yang merangkap tugas dan fungsinya tentu sikapnya terhadap disposisi yang diberikan berbeda dengan pegawai yang tidak merangkap tugas dan fungsi. Bagi pegawai yang merangkap tugas dan fungsinya ada waktunya dimana tugas yang satu bersamaan waktunya dengan tugas yang lain, walaupun kedua tugas dikerjakan dengan baik, namun harus tetap ada yang diprioritaskan. Tentunya pegawai lebih memilih memprioritaskan tugas dan fungsinya secara definitif.

Upaya untuk mengatasi kendala terkait struktur birokrasi pada GKN Manado adalah satker mengupayakan berkoordinasi dengan satker lingkup Kementerian Keuangan yang menempati GKN Manado untuk menempatkan beberapa ASN pada GKN Manado, dengan terlebih dahulu meminta izin kepada atasan yang bersangkutan, atau mengambil pegawai pelaksananya sendiri untuk ditempatkan juga pada GKN Manado sehingga koordinasi berjalan lebih cepat. Pegawai yang dipilih juga dianggap mampu untuk melaksanakan tugas dan fungsinya di GKN Manado.

Dari seluruh kendala yang ada, merupakan peran kepala satker sebagai pimpinan satker yang juga berpengaruh. Upaya para Kuasa Pengguna Anggaran (KPA) sebagai pengelola keuangan satker tentunya beragam bergantung dari karakter individunya masing-masing dan gaya kepemimpinan masing-masing. Namun sebagai upaya menjawab kendala-kendala yang ada, KPA masing-masing satker melakukan perannya dengan memaksimalkan kemampuan yang dimilikinya demi tujuan organisasi. Pada satker GKN Manado, KPA turun langsung untuk dapat memprioritaskan kegiatan yang lebih dahulu dikerjakan. Begitu pula peran KPA pada KPPBC Manado yang mengutamakan komunikasi antara KPA dan jajarannya maupun pelaksana terkait dengan visi, misi, dan tujuan organisasi, serta mengomunikasikan peran para jajaran dan pelaksananya pada setiap tugas dan fungsinya masing-masing. Dengan begitu KPA memberikan semangat kepada jajaran serta para pelaksananya.

\section{Penutup}

Kesimpulan dalam penelitian ini adalah pada dasarnya dalam proses penganggaran belanja, satker telah dibekali dasar-dasar hukum yang menjadi panduan mulai dari proses perencanaan dan penganggaran, pelaksanaan anggaran, pelaporan, pengawasan dan evaluasi. Dengan adanya panduan ini diharapkan pengelolaan belanja yang dipakai dengan efisien, efektif, dan tepat guna. Secara 
keseluruhan satker GKN Manado dan KPPBC Manado telah menggunakan dasar-dasar hukum yang ada dalam proses penganggaran belanjanya. Namun demikian perbandingan antara rencana anggaran yang tercantum dalam Rencana Penarikan Dana pada halaman III DIPA berbeda dengan realisasi anggaran yang dilakukan oleh satuan kerja.

Adapun kendala yang dihadapi oleh satker GKN Manado dan KPPBC Manado terkait dengan penganggaran belanja adalah sumber daya manusia yang belum memadai baik secara kuantitas maupun kompetensi terkait dengan pentingnya penganggaran belanja satker khususnya perencanaan anggaran pada satker GKN Manado dan KPPBC Manado. Sumber daya manusia menjadi penting untuk mengatasi kendala komunikasi yang terjadi pada GKN Manado dan KPPBC Manado dengan instansi atau pihak di luar satker, kualitas sumber daya manusia juga menentukan disposisi atau sikap pelaksana pada tugas dan fungsinya. Struktur birokrasi yang kurang tepat menjadi kendala pada ketersediaan sumber daya manusia atau penganggaran yang berkaitan dengan pihak di luar satker lingkup Kementerian Keuangan. Strategi dalam upaya untuk mengatasi kendala-kendala tersebut tentunya dengan menganalisa dengan tepat mulai dari proses perencanaan, penganggaran, realisasi anggaran, serta melakukan pengawasan, evaluasi, dan pelaporan yang rutin dilaksanakan. Selain itu, perlu didukung dengan distribusi sumber daya manusia sesuai dengan kebutuhan dan terus mengembangkan kompetensi sumber daya manusia yang ada, sehingga dapat membangun komunikasi baik itu secara relasi maupun dengan menggunakan sistem komunikasi. Dengan begitu kendalakendala yang ada dapat selalu terinformasikan kepada pimpinan dan dapat segera teratasi dengan lebih cepat. Selain itu diperlukan juga komitmen dari para pimpinan untuk tetap fokus kepada tujuan organisasi, sehingga dapat memberikan semangat yang sama, persepsi yang sama terkait dengan penganggaran belanja satker kepada para pegawai yang di bawahnya dan memberikan usulan yang membangun terkait satker yang dipimpinnya kepada organisasi yang ada di atasnya, dalam hal ini unit eselon I yang di atasnya.

Saran yang dapat diberikan bagi GKN Manado dan KPPBC Manado terkait dengan penganggaran belanja adalah: 1)perlu dilakukan distribusi dan pengembangan sumber daya manusia yang sesuai dan rutin, baik itu berupa bimbingan teknis dari unit eselon I yang berada di atas satker maupun pendidikan dan pelatihan yang dilakukan oleh Badan Pendidikan dan Pelatihan Keuangan RI, dan juga monitoring yang secara rutin dilakukan oleh internal satker tersebut terkait dengan penganggaran belanja satker. Hal ini penting agar proses penganggaran belanja satker GKN Manado dan KPPBC Manado menjadi semakin baik dari waktu ke waktu; 2) pengembangan Pengembangan dan pelatihan yang dilakukan tentu saja bukan hanya terkait dengan penganggaran belanja satker tetapi terkait bagaimana membangun komunikasi yang baik untuk relasi internal maupun eksternal satker. Selain itu juga pengembangan dan pelatihan yang membangun awareness para pegawai terkait pentingnya organisasi untuk mewujudkan cita-cita organisasi, sehingga secara personal pegawai memiliki tanggung jawab atas tugas dan fungsi yang diembannya. Pelatihan juga dilakukan terkait dengan membuat kebijakan agar satker dapat membuat prosedur dengan baik dan memenuhi seluruh kebutuhan yang diperlukan satker; 3) diperlukan komitmen dari para pemimpin yang berkarakter baik, fokus kepada tujuan organisasi, komunikatif dengan para pegawai yang ada dengan mengkomunikasikan visi, misi, dan tujuan organisasi kepada para pegawai; 4) perlu diusulkan kepada pemerintah pusat untuk membuka pelabuhan Bitung sebagai pusat logistik di wilayah timur Indonesia, sehingga kehadiran KPPBC Manado dapat lebih dirasakan, kemajuan masyarakat Sulawesi Utara semakin tinggi, dan juga daya beli masyarakat meningkat pula, dan pada akhirnya pendapatan pajak Sulawesi Utara akan semakin meningkat.

\section{Daftar Pustaka}

Bastian, Indra, (2010), Akuntansi Sektor Publik Suatu Pengantar Edisi Ketiga, Jakarta: Penerbit Erlangga.

Jauhari, (2017), Pengaruh Perencanaan Anggaran Dan Pelaksanaan Anggaran Terhadap Serapan Anggaran Satuan Kerja Wilayah Pembayaran KPPN Bandung I Dan KPPN Bandung II, Tesis: Program Studi Magister Manajemen Universitas Pasundan. Bandung.

Murwanto, Rahmadi, Insyafiah, dan Subkhan, (2006), Manajemen Kas Sektor Publik, Lembaga Pengkajian Keuangan Publik Dan Akuntansi Pemerintah (LPKPAP), Badan Pendidikan dan Pelatihan Keuangan, ISBN $979-25$ - 8315 - 7. Jakarta.

Gumelar, Galih, (2018), Sri Mulyani Ancam Setop Anggaran K/L yang Sering Revisi DIPA, https://www.cnnindonesia.com/ekonomi/20180221114649-532-277691/sri-mulyani-ancamsetop-anggaran-k-1-yang-sering-revisi-dipa, diakses pada tanggal 24 Februari 2018. 
Sugiyono, (2015), Memahami Penelitian Kualitatif, Bandung: Alfabeta.

Ibrahim, (2015), Metodologi Penelitian Kualitatif Panduan Penelitian Beserta Contoh Proposal Kualitatif, Bandung: Alfabeta.

Republik Indonesia. Undang-Undang Dasar Tahun 1945 serta perubahannya. Jakarta. Undang-Undang Nomor 17 Tahun 2003 tentang Keuangan Negara. Jakarta. Undang-Undang Nomor 1 Tahun 2004 tentang Perbendaharaan Negara. Jakarta. Peraturan Menteri Keuangan Nomor 190/PMK.05/2012 Tentang Tata Cara Pembayaran Dalam Rangka Pelaksanaan Anggaran Pendapatan dan Belanja Negara. Jakarta.

Standar. Jakarta.

Peraturan Menteri Keuangan Nomor 214/PMK.05/2013 Tentang Bagan Akun Peraturan Menteri Keuangan Nomor 270/PMK.05/2014 tentang Penerapan Standar Akuntansi Pemerintahan Berbasis Akrual Pada Pemerintah Pusat. Jakarta. Peraturan Menteri Keuangan Nomor 277/PMK.05/2014 tentang Rencana Penarikan Dana, Rencana Penerimaan Dana, Rencana Penerimaan Dana, Dan Perencanaan Kas. Jakarta.

Peraturan Menteri Keuangan Nomor 143/PMK.02/2015 tentang Petunjuk Penyusunan dan Penelaahan Rencana Kerja dan Anggaran Kementerian Negaral Lembaga Dan Pengesahan Daftar Isian Pelaksanaan Anggaran. Jakarta.

Keputusan Menteri Keuangan Nomor 418/KMK.01/2012 tentang Perwakilan Kementerian Keuangan, Sekretariat Perwakilan Kementerian Keuangan, dan Pengelolaan Gedung Keuangan Negara Di Daerah. Jakarta. 